\title{
IMC Growth of Solid State Reaction between Ni UBM and Sn-3Ag-0.5Cu and Sn-3.5Ag Solder Bump Using Ball Place Bumping Method during Aging
}

\author{
Shinji Ishikawa ${ }^{1, *}$, Eiji Hashino $^{1}$, Taro Kono $^{2}$ and Kohei Tatsumi ${ }^{1}$ \\ ${ }^{1}$ Advanced Technology Research Laboratories, Nippon Steel Corp., Futtsu, 293-8511, Japan \\ ${ }^{2}$ New Materials Division Nippon Steel Corp., Tokyo, 100-8071, Japan
}

\begin{abstract}
The bumps for flip chip interconnection are becoming smaller and smaller. Since lead-free solders became popular, Ni-based under bump metallization (UBM) has attracted attention in recent years because of their slower reaction rate than traditional Cu-based UBM. However, there is little data concerning the solid state reaction between small lead-free solder bumps and Ni-based UBM. In this work, Sn-3Ag-0.5Cu and Sn$3.5 \mathrm{Ag}$ solder bumps were fabricated with $110-\mu \mathrm{m}$-diameter solder balls on electrolytic $\mathrm{Ni}$, and the growth kinetics of intermetallic compound (IMC) layers and the morphology of bumps during long-term aging were investigated. The IMC layer exhibited parabolic growth, and the activation energy values for the $\mathrm{Sn}-3 \mathrm{Ag}-0.5 \mathrm{Cu}$ or $\mathrm{Sn}-3.5 \mathrm{Ag}$ solder/Ni UBM were obtained. The growth rate accelerated at $463 \mathrm{~K}$ or above. $(\mathrm{Ni}, \mathrm{Cu})_{3} \mathrm{Sn}_{4}$ or $\mathrm{Ni}_{3} \mathrm{Sn}_{4}$ IMC was formed mainly at the solder/Ni interface after long-term aging. Large voids were formed at the solder/IMC interface at $463 \mathrm{~K}$ or above. The voids are the result of stress by volume expansion due to IMC growth. Coarse $\mathrm{Ag}_{3} \mathrm{Sn}$ grains were observed adjacent to the voids and contributed to void initiation.
\end{abstract}

(Received May 19, 2005; Accepted October 4, 2005; Published November 15, 2005)

Keywords: solder, lead-free, electrolytic nickel, flip chip, intermetallic compound, isothermal aging, microstructure, growth kinetics

\section{Introduction}

With progress in high-density, high-speed technologies for semiconductor devices in recent years, high performance and substantial downsizing of electronic equipment have been achieved. These advancements in LSI technology has led to an increase in the number of input and output pins and a decrease in the size and pitch of electrodes. With this situation, some chip interconnection technologies using bonding wires are being replaced by flip chip interconnection technologies, where bumps are formed on chip electrodes and the chips are bonded via these bumps. In advanced areas of flip chip interconnection, ultra fine pitches and minimized bumps are required to meet the demand for higher density packages. On the other hand, using lead-free solders for flip chip interconnection instead of traditional eutectic $\mathrm{Sn}-\mathrm{Pb}$ solders in electronics has increased from the viewpoint of environmental-friendly technology. ${ }^{1)}$ Therefore, in flip chip technologies, both fine pitch interconnection and lead-free solder are to be developed simultaneously.

Since the introduction of flip chip technology by IBM in the 1960s, under bump metallization (UBM) has become essential in solder bumps. ${ }^{2)}$ As lead-free solders have become popular in recent years, Ni-based UBM has attracted attention because of their slower reaction rate than traditional $\mathrm{Cu}$-based UBM. Many studies have been devoted to understanding the interactions between $\mathrm{Sn}$-rich solders and Nibased UBMs. While many studies on the intermetallic compounds (IMCs) formed as a result of interfacial reactions between $\mathrm{Sn}-\mathrm{Ag}-\mathrm{Cu}$ solders and different Ni-based UBMs, such as $\mathrm{Cu} / \mathrm{Ni} / \mathrm{Au},{ }^{3-5)} \mathrm{Al} / \mathrm{Ni}(\mathrm{V}) / \mathrm{Cu}^{6,7)}$ and $\mathrm{Ni}(\mathrm{P}) / \mathrm{Au}^{8-12)}$ have been reported, there have been few studies on the IMCs formed between $\mathrm{Sn}-\mathrm{Ag}-\mathrm{Cu}$ solders and pure $\mathrm{Ni}$ UBM without an $\mathrm{Au}$ protective barrier. Furthermore, data on solid state reactions between especially small lead-free solder

*E-mail: ishikawa@re.nsc.co.jp bump and pure Ni UBM are not sufficient. It is expected that with a different volume of bumps, their morphology and their growth rate under thermal aging conditions change.

Currently, ultra fine pitch bumps, under $200 \mu \mathrm{m}$ for flip chip interconnection, are fabricated mainly using the electroplating solder bump method. In this method, it is difficult to form bumps of ternary or more solder composition. This may be one reason that we do not have sufficient data for the ultra fine pitch bumps of lead-free solder, such as the $\mathrm{Sn}-\mathrm{Ag}-\mathrm{Cu}$ ternary system. However, a new ball-place-bumping method has been developed by the authors. ${ }^{13)}$ This technique industrially achieved fine pitch bumping and a decrease in the limitation concerning the solder composition of bumps. With this method, solders for flip chip interconnection will change to ternary or more systems because of beneficial properties such as thermal fatigue. ${ }^{14)}$

This paper compares interaction between three solder bumps ( $\mathrm{Sn}-3 \mathrm{Ag}-0.5 \mathrm{Cu}, \mathrm{Sn}-3.5 \mathrm{Ag}$ and for comparison, $\mathrm{Sn}-$ $37 \mathrm{~Pb}$ ) fabricated using the ball-place-bumping method and electrolytic Ni UBM. The morphology of IMC formed under reflow and thermal aging conditions was observed. IMC growth kinetics was assessed and compared for the three systems. This comparison among the three solder/UBM combinations will aid an understanding of the effects of solder composition and UBM composition on the interfacial reaction.

\section{Experimental}

The Si substrates used in this study were electrolytic Ni UBMs with $110-\mu \mathrm{m}$ diameter and $5-\mu \mathrm{m}$ thickness formed on a Si wafer fabricated by a commercial organization. To obtain basic data, UBM composed of only Ni without any surface protective metals such as Au was used. The bumps were formed on the UBM using the ball-placing method as shown in Fig. 1(a). The diameter of the solder ball used was $110 \mu \mathrm{m}$. After the UBMs were cleaned with $0.1 \mathrm{~N} \mathrm{HCl}$ 
Ball Placed

(a)

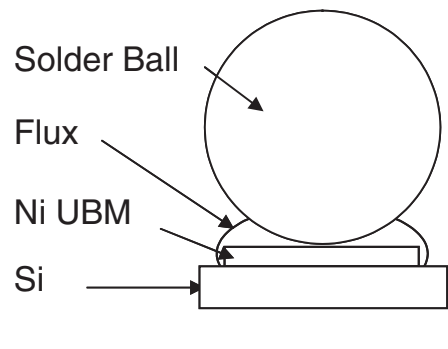

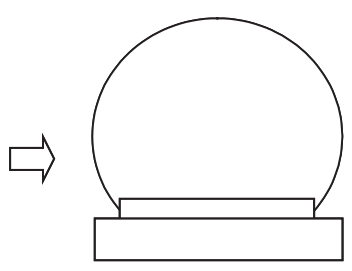

After Reflowed

(b)
Fig. 1 Schematic illustration of bump formation.

solution for $300 \mathrm{~s}, \mathrm{Sn}-3 \mathrm{Ag}-0.5 \mathrm{Cu}, \mathrm{Sn}-3.5 \mathrm{Ag}$ and $\mathrm{Sn}-37 \mathrm{~Pb}$ solder balls were placed on the UBM with RMA-type flux. They were then subjected to reflow treatment twice with a peak temperature of $533 \mathrm{~K}$ to fit the initial conditions of common flip chip bonding. The temperature profile of the reflow is shown in Fig. 2.

The samples were isothermally aged at $398,423,448,463$ and $473 \mathrm{~K}$ for $0.18 \times 10^{6} \mathrm{~s}, 0.72 \times 10^{6} \mathrm{~s}, 1.8 \times 10^{6} \mathrm{~s}, 3.6 \times$ $10^{6} \mathrm{~s}$ and $7.2 \times 10^{6} \mathrm{~s}$. After each of the aging steps, the samples were mounted in epoxy and metallographically polished for micro-structural characterization. Micro-structural and chemical analyses of the samples were conducted using an optical microscope, a scanning electron microscope (SEM) and an electron probe micro analyzer (EPMA). The layer thickness was measured using image analysis software to obtain the total area of the intermetallic layer.

\section{Results and Discussion}

\subsection{Morphology of IMC}

Typical cross-sectional views of the interfacial microstructure of the three solder/UMB systems $(\mathrm{Sn}-3 \mathrm{Ag}-0.5 \mathrm{Cu}$,

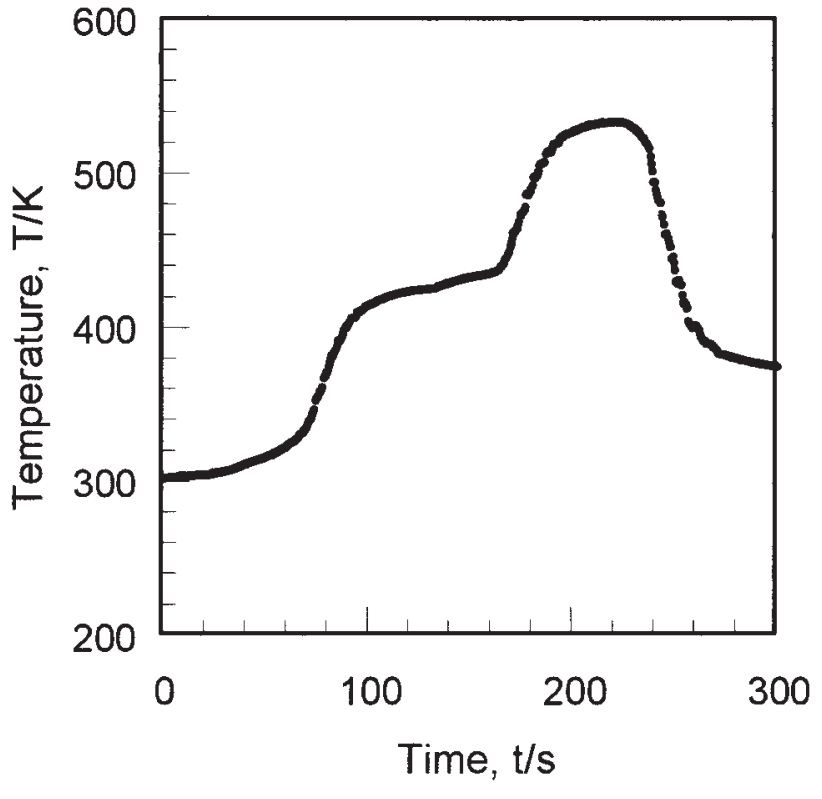

Fig. 2 Temperature profile of the reflow treatment.

$\mathrm{Sn}-3.5 \mathrm{Ag}$ and $\mathrm{Sn}-37 \mathrm{~Pb}$ solder with electrolytic Ni UBM) after aging up to $7.2 \times 10^{6} \mathrm{~s}$ at $398,423,448$, and $473 \mathrm{~K}$ are shown in Figs. $3-5$. The IMC layer in the $\mathrm{Sn}-3 \mathrm{Ag}-0.5 \mathrm{Cu}$ solder/electrolytic Ni UBM system had chunky, needle-like, grains at the initial state. The IMC layer in the Sn-3.5Ag and $\mathrm{Sn}-37 \mathrm{~Pb}$ solder/electrolytic Ni UBM system had smoother contour lines. This morphology is in agreement with previous reports on a $\mathrm{Cu} / \mathrm{Ni} / \mathrm{Au}$ BGA pad obtained in the $\mathrm{Sn}-3 \mathrm{Ag}-$ $0.5 \mathrm{Cu}$ and $\mathrm{Sn}-3.5 \mathrm{Ag}$ solder systems ${ }^{4)}$ and sputtered $\mathrm{Ni} / \mathrm{Au}$ UBM in the $\mathrm{Sn}-3.5 \mathrm{Ag}$ and $\mathrm{Sn}-37 \mathrm{~Pb}$ solder systems. ${ }^{10)}$ The IMCs of the three systems evolved over all aging conditions were studied. However, Ni UBM was fully consumed at $473 \mathrm{~K}$ after aging for $7.2 \times 10^{6} \mathrm{~s}$ in the $\mathrm{Sn}-3 \mathrm{Ag}-0.5 \mathrm{Cu}$ solder

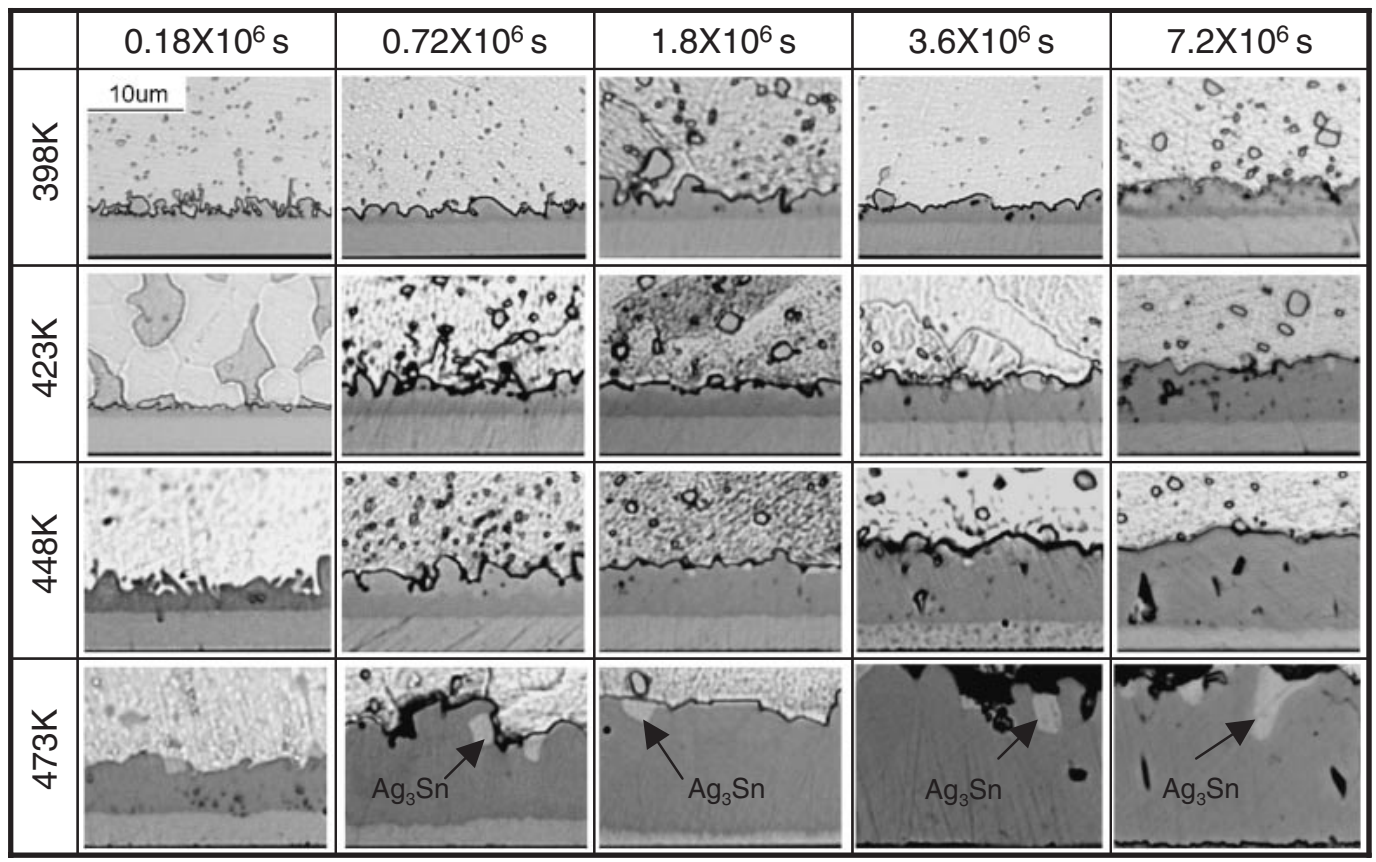

Fig. 3 Optical microscope image of $\mathrm{Sn}-3 \mathrm{Ag}-0.5 \mathrm{Cu}$ solder/electrolytic Ni joints after aging for up to $7.2 \times 10^{6} \mathrm{~s}$ from 398 to $473 \mathrm{~K}$. 


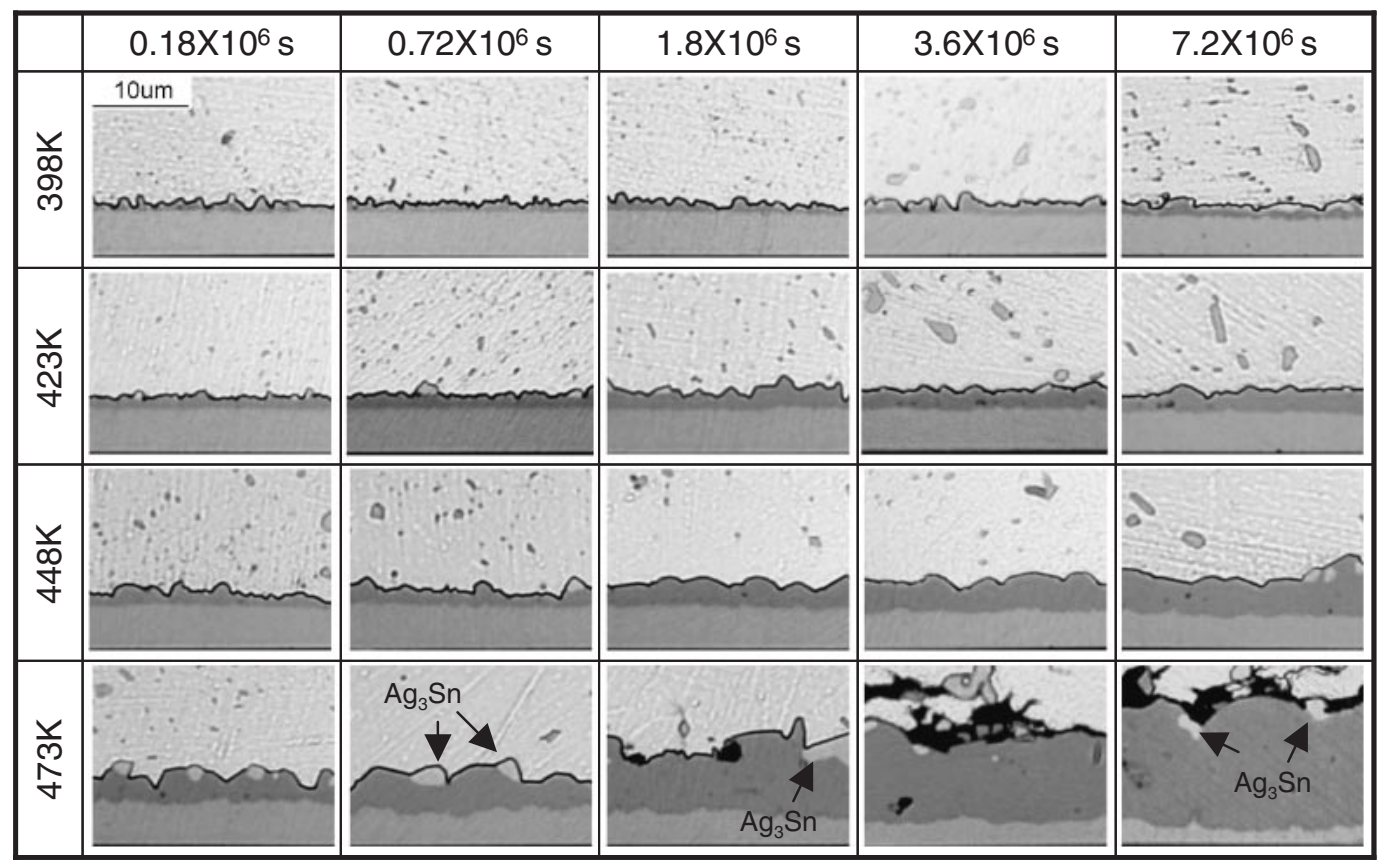

Fig. 4 Optical microscope image of Sn-3.5Ag solder/electrolytic Ni joints after aging for up to $7.2 \times 10^{6} \mathrm{~s}$ from 398 to $473 \mathrm{~K}$.

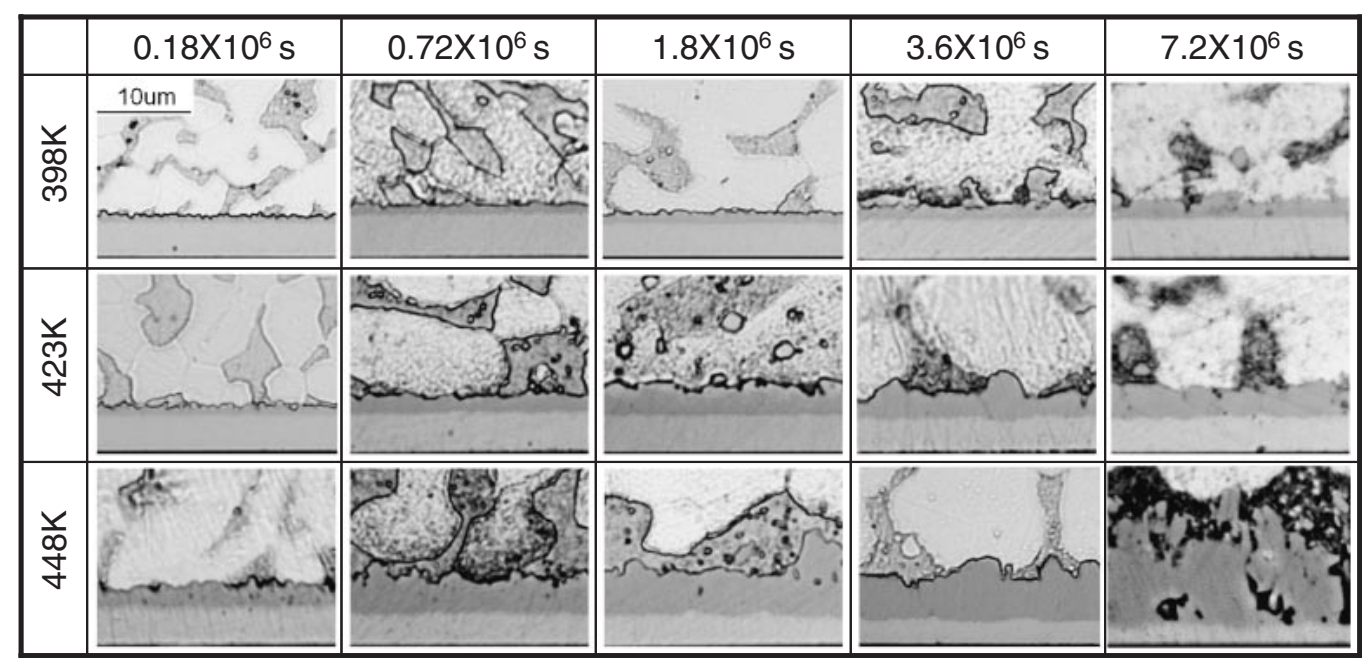

Fig. 5 Optical microscope image of Sn-37Pb solder/electrolytic Ni joints after aging for up to $7.2 \times 10^{6}$ s from 398 to $448 \mathrm{~K}$.

system. The contour lines of IMC of $\mathrm{Sn}-3 \mathrm{Ag}-0.5 \mathrm{Cu}$ gradually became smooth after long-term aging. The growth rate of IMC was most rapid in the order of $\mathrm{Sn}-3 \mathrm{Ag}-0.5 \mathrm{Cu}$, $\mathrm{Sn}-37 \mathrm{~Pb}$, and $\mathrm{Sn}-3.5 \mathrm{Ag}$. This is consistent with the research by Sharif et al. on $\mathrm{Ni} / \mathrm{Au} \mathrm{UMB} / \mathrm{Sn}-3 \mathrm{Ag}-0.5 \mathrm{Cu}$ and $\mathrm{Sn}-$ $3.5 \mathrm{Ag}$ solder systems. ${ }^{4)}$ While Sharif et al. also reported that the entire $5-\mu \mathrm{m}$ Ni layer was consumed from the substrate pads after aging for $1.4 \times 10^{6} \mathrm{~s}$ at $463 \mathrm{~K}$, in the present work, full consumption required $7.2 \times 10^{6} \mathrm{~s}$ at $473 \mathrm{~K}$. This difference is due to the influence of the ball diameter used, that is, the diameter of the solder ball used by Sharif et al. of $760 \mu \mathrm{m}$ was much larger than that of this work $(110 \mu \mathrm{m})$. Meanwhile, $\mathrm{He}$ et al. reported that IMC in the sputtered Ni/Au UBM/Sn$3.5 \mathrm{Ag}$ solder system showed more rapid growth than the sputtered $\mathrm{Ni} / \mathrm{Au} \mathrm{UBM} / \mathrm{Sn}-37 \mathrm{~Pb}$ solder system. ${ }^{10)}$ This difference is attributed to the existence of $\mathrm{Au}$, because, in their system, a layer of $\mathrm{Au}-\mathrm{Ni}-\mathrm{Sn}$ ternary IMC was formed on the top of the $\mathrm{Ni}-\mathrm{Cu}-\mathrm{Sn}$ IMC layer and must have suppressed the growth of IMC.

When aged at $473 \mathrm{~K}$, large voids were formed in the Sn$3 \mathrm{Ag}-0.5 \mathrm{Cu}$ solder after $0.72 \times 10^{6} \mathrm{~s}$ and in the $\mathrm{Sn}-3.5 \mathrm{Ag}$ solder after $1.8 \times 10^{6} \mathrm{~s}$ as shown in Figs. 3 and 4 , respectively. The thickness of IMC at these times was larger than $10 \mu \mathrm{m}$. In the case of $\mathrm{Sn}-37 \mathrm{~Pb}$ solder, such voids were not observed despite the formation of about $10-\mu \mathrm{m}$ thick IMC. Such voids have not been previously reported in much research on Ni-based UMB/high Sn solder joints, and were first observed in this work. The reason that has it not been reported up to now is that the volume of the bumps is especially small in this work. In addition, in the solders, Sn$3 \mathrm{Ag}-0.5 \mathrm{Cu}$ and $\mathrm{Sn}-3.5 \mathrm{Ag}$, where voids were formed after long-term aging at $473 \mathrm{~K}$, large $\mathrm{Ag}_{3} \mathrm{Sn}$ particles, shown in Figs. 3-4, were observed at the boundary region between the solder and IMC. 

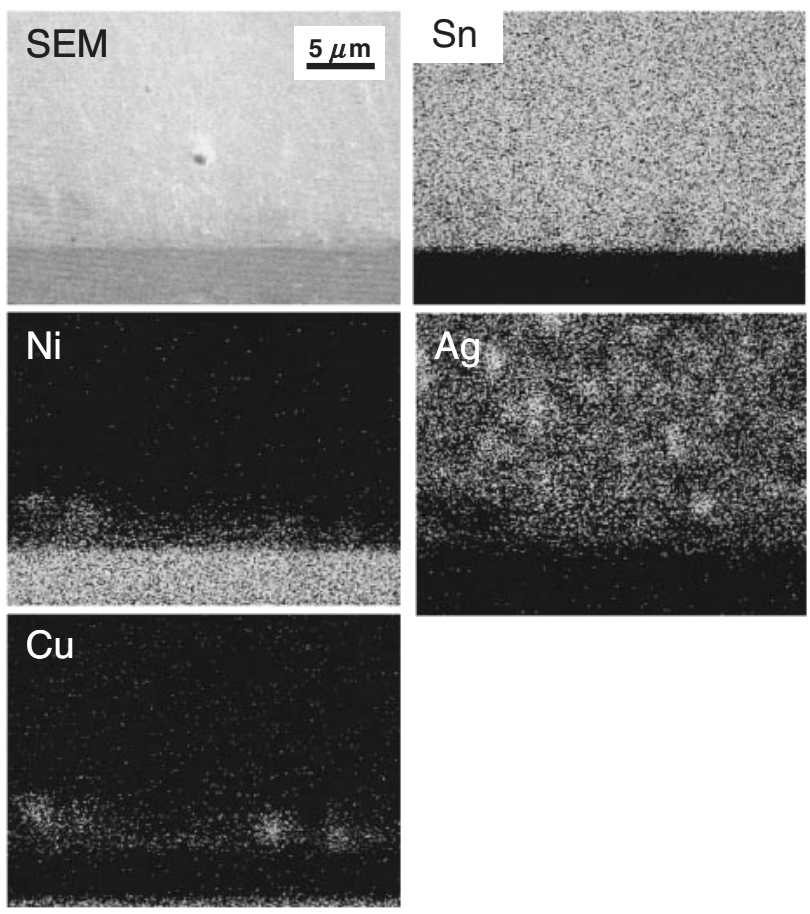

Fig. 6 SEM image and EPMA mapping of Sn-3Ag-0.5Cu solder/electrolytic Ni joints as-reflowed.
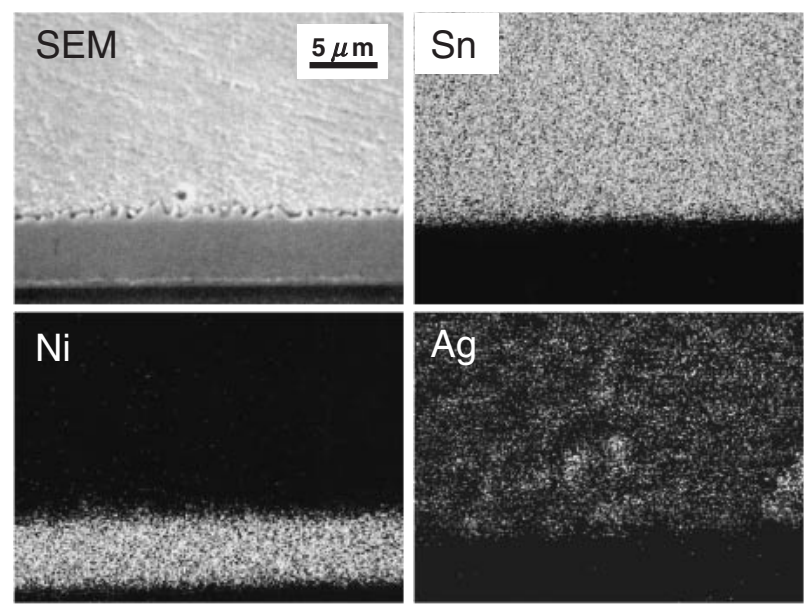

Fig. 7 SEM image and EPMA mapping of Sn-3.5Ag solder/electrolytic Ni joints as-reflowed.

The EPMA analysis results of as-reflowed and aged $\mathrm{Sn}-$ $3 \mathrm{Ag}-0.5 \mathrm{Cu}$ and $\mathrm{Sn}-3.5 \mathrm{Ag}$ solders joints for $1.8 \times 10^{6} \mathrm{~s}$ at $423 \mathrm{~K}$ are shown in Figs. 6-11. The IMCs formed between the $\mathrm{Sn}-3 \mathrm{Ag}-0.5 \mathrm{Cu}$ solder and electrolytic $\mathrm{Ni}$ were $\mathrm{Ni}-\mathrm{Cu}-\mathrm{Sn}$ ternary IMC, while those of the $\mathrm{Sn}-3.5 \mathrm{Ag}$ solder and $\mathrm{Sn}-$ $37 \mathrm{~Pb}$ were $\mathrm{Ni}-\mathrm{Sn}$ binary IMC. Neither $\mathrm{Ag}$ of $\mathrm{Sn}-3 \mathrm{Ag}-0.5 \mathrm{Cu}$ and $\mathrm{Sn}-3.5 \mathrm{Ag}$ solder nor $\mathrm{Pb}$ of $\mathrm{Sn}-37 \mathrm{~Pb}$ solder was involved in interfacial reactions. In this study, EPMA quantitative analysis confirmed that IMC formed at the interface of the sample after long-term aging is $(\mathrm{Ni}, \mathrm{Cu})_{3} \mathrm{Sn}_{4}$ or $\mathrm{Ni}_{3} \mathrm{Sn}_{4}$. The composition of $\mathrm{Cu}$ in $(\mathrm{Ni}, \mathrm{Cu})_{3} \mathrm{Sn}_{4}$ in the $\mathrm{Sn}-3 \mathrm{Ag}-0.5 \mathrm{Cu}$ solder was 5.3 mass $\% \mathrm{Cu}$ at $423 \mathrm{~K}$ and 2.5 mass $\% \mathrm{Cu}$ at $473 \mathrm{~K}$. Since the amount of $\mathrm{Cu}$ was limited in the solder and
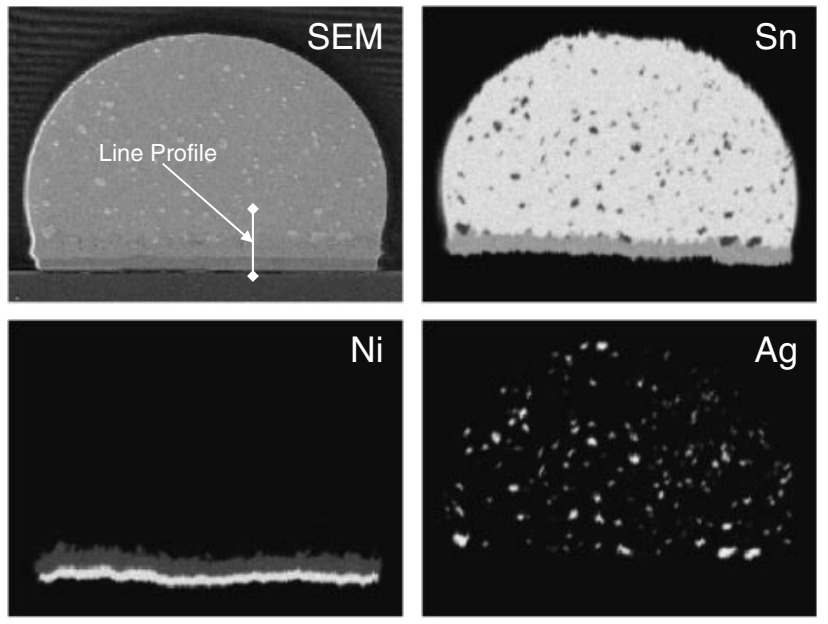

Fig. 8 Whole bump EPMA mapping of $\mathrm{Sn}-3 \mathrm{Ag}-0.5 \mathrm{Cu}$ solder/electrolytic $\mathrm{Ni}$ joints after aging for $7.2 \times 10^{6} \mathrm{~s}$ at $423 \mathrm{~K}$.
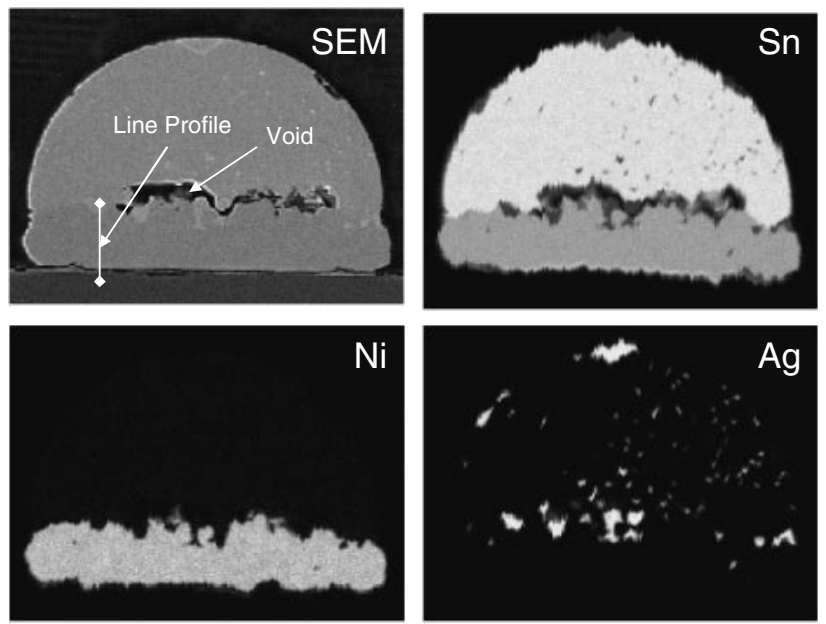

Fig. 9 Whole bump EPMA mapping of $\mathrm{Sn}-3 \mathrm{Ag}-0.5 \mathrm{Cu}$ solder/electrolytic $\mathrm{Ni}$ joints after aging for $7.2 \times 10^{6} \mathrm{~s}$ at $473 \mathrm{~K}$.
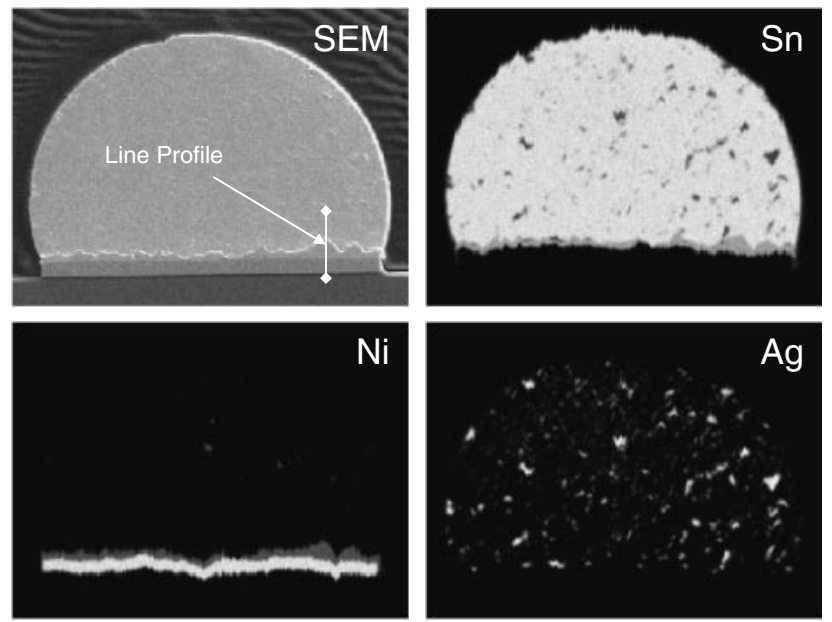

Fig. 10 Whole bump EPMA mapping of $\mathrm{Sn}-3.5 \mathrm{Ag}$ solder/electrolytic Ni joints after aging for $7.2 \times 10^{6} \mathrm{~s}$ at $423 \mathrm{~K}$. 

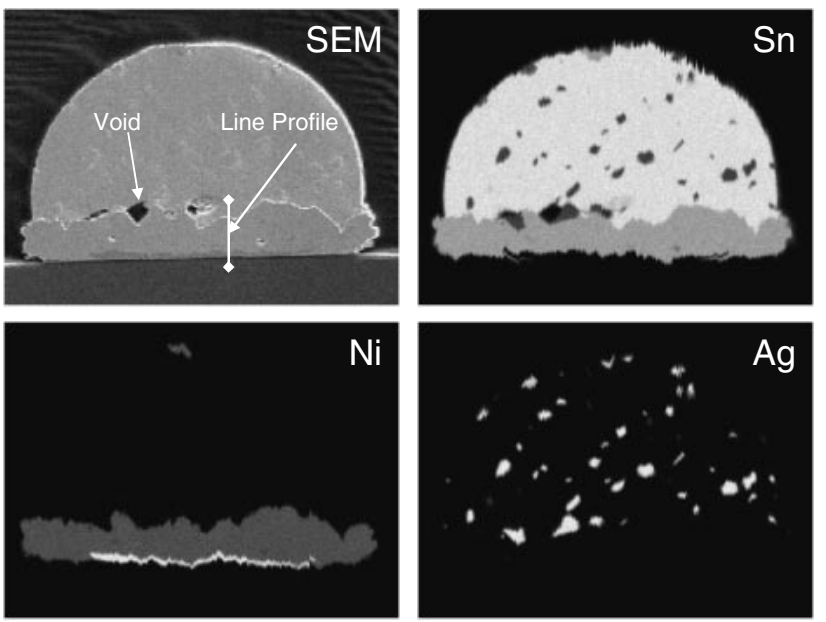

Fig. 11 Whole bump EPMA mapping of Sn-3.5Ag solder/electrolytic Ni joints after aging for $7.2 \times 10^{6} \mathrm{~s}$ at $473 \mathrm{~K}$.

(a)

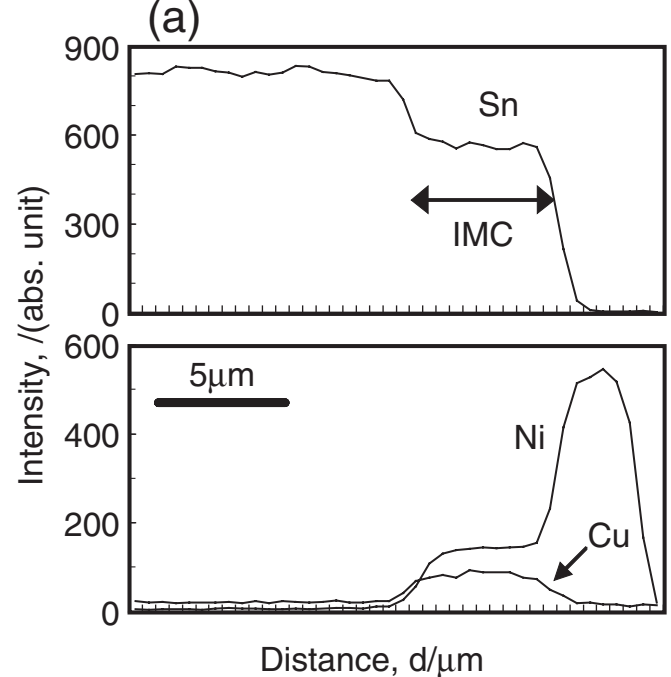

the volume of IMC at $473 \mathrm{~K}$ was larger than at $423 \mathrm{~K}$, the $\mathrm{Cu}$ content at $473 \mathrm{~K}$ was smaller than at $423 \mathrm{~K}$. The quantitative results of EPMA analysis for the IMCs formed at the interface in this study are shown in Table 1 and Figs. 12-13.

Previous results showed that the IMCs formed at the interface of $\mathrm{Sn}-\mathrm{Ag}-\mathrm{Cu}$ solder and pure $\mathrm{Ni}$ depended on the $\mathrm{Cu}$ concentration in the solder material. Zeng et al. ${ }^{6)}$ pointed out that the formation of $(\mathrm{Cu}, \mathrm{Ni})_{6} \mathrm{Sn}_{5}$ dominated at the

Table 1 EPMA composition analysis results of IMCs formed at the $\mathrm{Sn}-$ $\mathrm{Ag}-\mathrm{Cu} / \mathrm{Ni}$ interface.

\begin{tabular}{cccccc}
\multirow{2}{*}{ Solder } & \multicolumn{2}{c}{} & \multicolumn{2}{c}{ (mass\%) } \\
\hline \multirow{2}{*}{$\mathrm{Sn}-3 \mathrm{Ag}-0.5 \mathrm{Cu}$} & $\mathrm{Nn}$ & $\mathrm{Ni}$ & $\mathrm{Cu}$ & $\mathrm{C}$ \\
\hline \multirow{2}{*}{$\mathrm{Sn}-3.5 \mathrm{Ag}$} & $423 \mathrm{~K}$ & 66.0 & 27.5 & 5.3 & Bal. \\
\cline { 2 - 6 } & $473 \mathrm{~K}$ & 64.3 & 31.7 & 2.5 & Bal. \\
\hline & $423 \mathrm{~K}$ & 65.8 & 32.5 & - & Bal. \\
\cline { 2 - 6 } & $473 \mathrm{~K}$ & 66.4 & 30.0 & - & Bal. \\
\hline
\end{tabular}

(b)

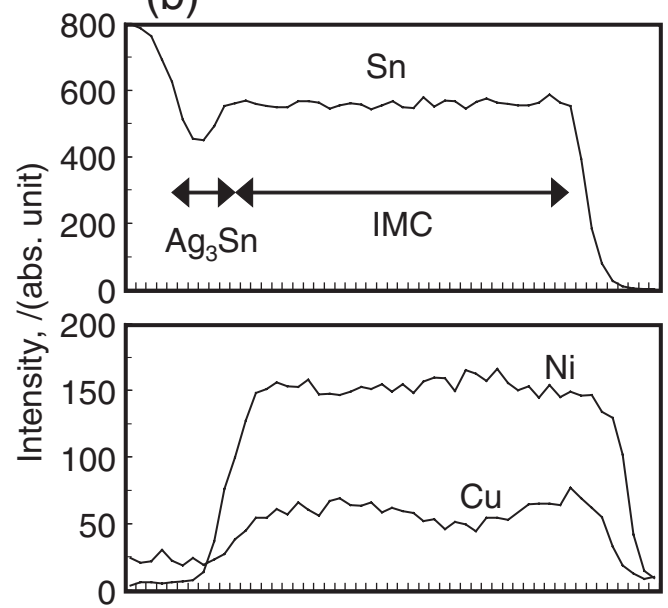

Distance, $\mathrm{d} / \mu \mathrm{m}$

Fig. 12 Line profile of EPMA mapping of Sn-3Ag-0.5Cu solder/electrolytic Ni joints after aging for $7.2 \times 10^{6} \mathrm{~s}(\mathrm{a})$ at $423 \mathrm{~K}$ and (b) at $473 \mathrm{~K}$.

(a)

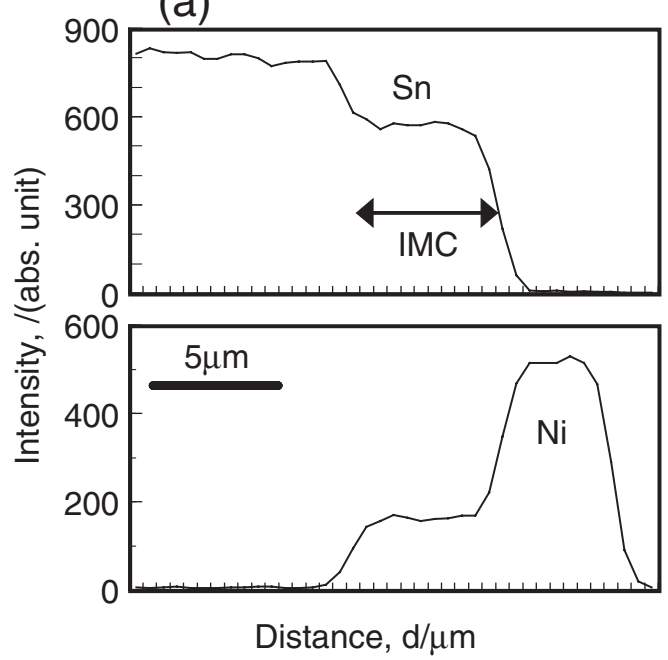

(b)

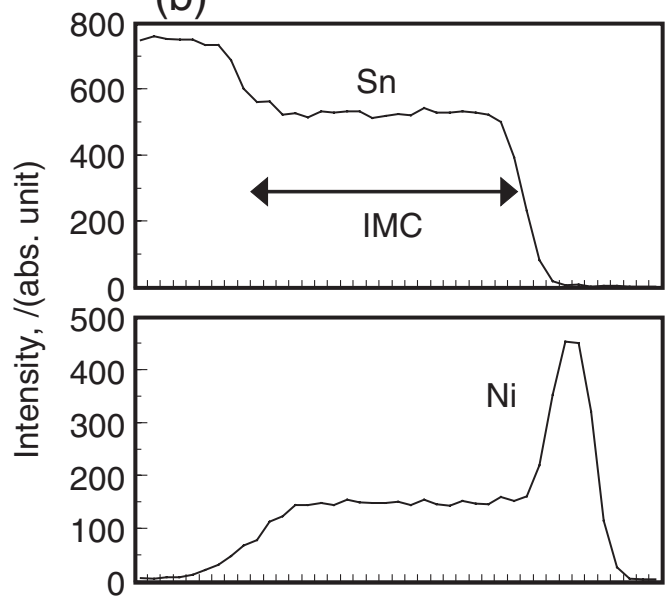

Distance, $\mathrm{d} / \mu \mathrm{m}$

Fig. 13 Line profile of EPMA mapping of Sn-3.5Ag solder/electrolytic Ni joints after aging for $7.2 \times 10^{6} \mathrm{~s}$ (a) at $423 \mathrm{~K}$ and (b) at $473 \mathrm{~K}$. 
(a)

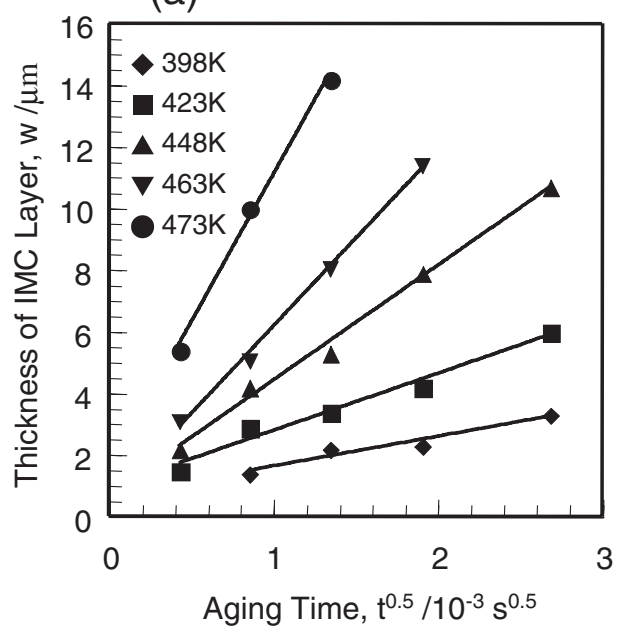

(b)

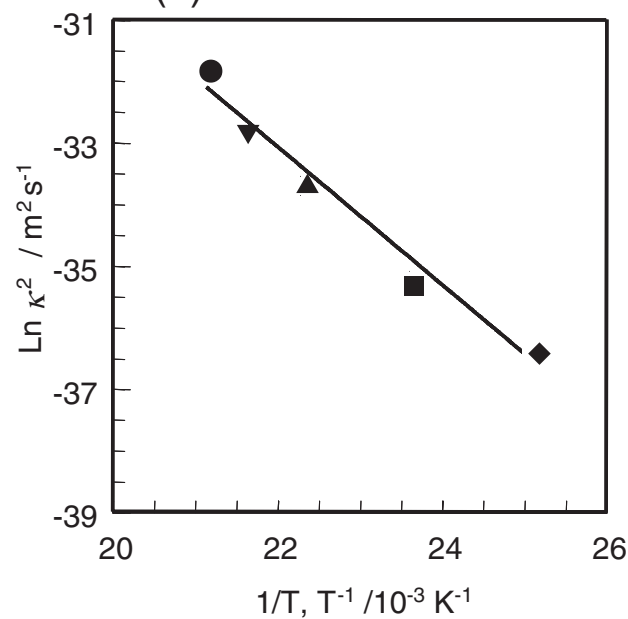

Fig. 14 (a) Average thickness of the IMC layer of $\mathrm{Sn}-3 \mathrm{Ag}-0.5 \mathrm{Cu}$ solder/electrolytic Ni joints with aging time and temperature and (b) Arrhenius plot for the growth of the IMC layer.

(a)

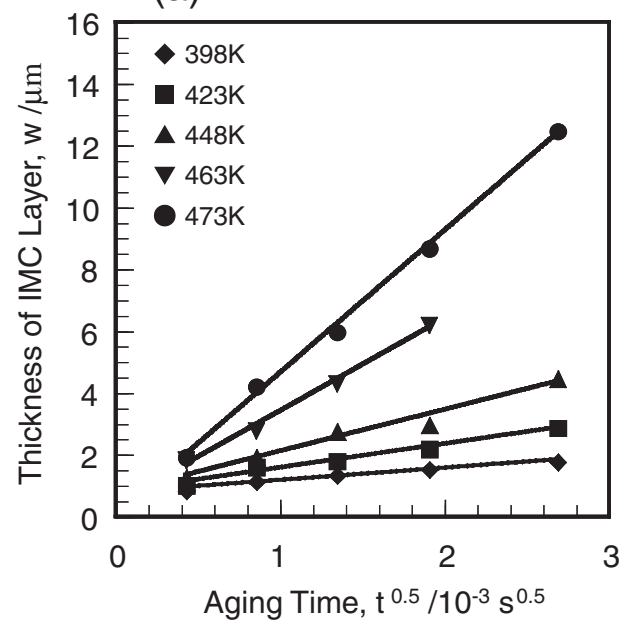

(b)

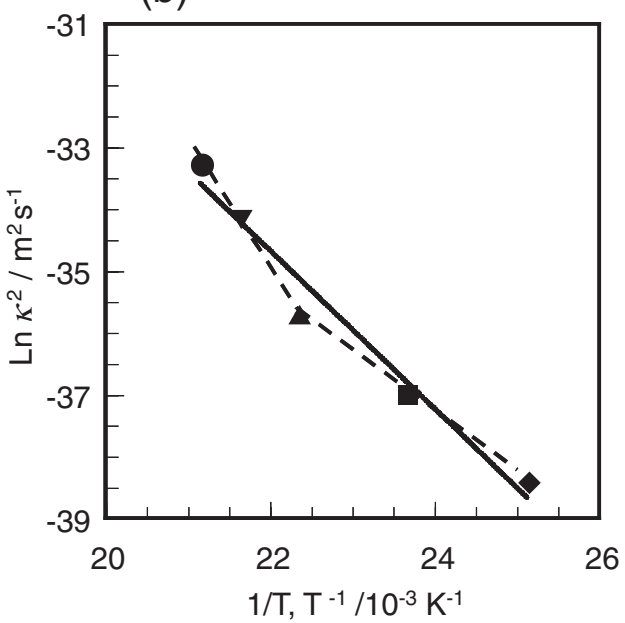

Fig. 15 (a) Average thickness of the IMC layer of $\mathrm{Sn}-3.5 \mathrm{Ag}$ solder/electrolytic Ni joints with aging time and temperature and (b) Arrhenius plot for the growth of the IMC layer.

interface when the $\mathrm{Cu}$ concentration in the solder was more than 0.6 mass $\%$. In addition, when the $\mathrm{Cu}$ concentration in the solder was so small, $(\mathrm{Ni}, \mathrm{Cu})_{3} \mathrm{Sn}_{4}$ was formed at the interface. In fact, in the $\mathrm{Sn}-0.2$ mass $\% \mathrm{Cu}$ solder, the product of the solder reaction with $\mathrm{Ni}$ was $(\mathrm{Ni}, \mathrm{Cu})_{3} \mathrm{Sn}_{4}$, and in the $\mathrm{Sn}-0.7 \mathrm{mass} \% \mathrm{Cu}$ solder, the product of the solder reaction with $\mathrm{Ni}$ was $\left.(\mathrm{Cu}, \mathrm{Ni})_{6} \mathrm{Sn}_{5} .{ }^{15}\right)$ Further, in the $\mathrm{Sn}-3.8$ mass \% Ag-0.7 mass\% Cu solder, $(\mathrm{Cu}, \mathrm{Ni})_{6} \mathrm{Sn}_{5}$ was formed at the interface. ${ }^{12)}$ The morphology change in $\mathrm{Sn}-3 \mathrm{Ag}-0.5 \mathrm{Cu}$ solder in Fig. 3 and the quantitative analysis results in Table 1 were in agreement with these results. Since a small amount of $\mathrm{Cu}$ exists, the IMC formed first is considered to be $(\mathrm{Cu}, \mathrm{Ni})_{6} \mathrm{Sn}_{5}$ that has chunky, needle-like grains. ${ }^{7)}$ After prolonged aging, however, the lack of $\mathrm{Cu}$ lead to the formation of a continuous $(\mathrm{Ni}, \mathrm{Cu})_{3} \mathrm{Sn}_{4}$ layer. On the other hand, IMCs formed by the reaction between $\mathrm{Sn}-3.5 \mathrm{Ag}$ solder or $\mathrm{Sn}-37 \mathrm{~Pb}$ solder and electrolytic Ni UBM were continual $\mathrm{Ni}_{3} \mathrm{Sn}_{4}$ because of the lack of $\mathrm{Cu}$.

In this work, $\mathrm{Ag}_{3} \mathrm{Sn}$ was observed in the form of small particles distributed in the body of the solder bumps at the initial state. In addition, $\mathrm{Ag}_{3} \mathrm{Sn}$ grains obviously become larger by coalescence with the progress of aging in Figs. 811. There was no large branch-like or plate-like phase, even in high-temperature, long-term aging for $7.2 \times 10^{6} \mathrm{~s}$ at $473 \mathrm{~K}$.

\subsection{Growth kinetics of IMC}

The thickness of $(\mathrm{Ni}, \mathrm{Cu})_{3} \mathrm{Sn}_{4}$ or $\mathrm{Ni}_{3} \mathrm{Sn}_{4}$ IMC in the three solder/UBM systems is shown as the function of aging time and temperature in Figs. 14(a)-16(a). The thickness of IMC increased linearly with the square root of the aging time at each aging temperature. This indicates that the IMC growth in all the systems studied is a diffusion-controlled process. The growth rate constant at a particular temperature, $k$, can be calculated from the slope of the linear fitting lines. The temperature dependence of $k$ can be represented by the Arrhenius equation: 
(a)

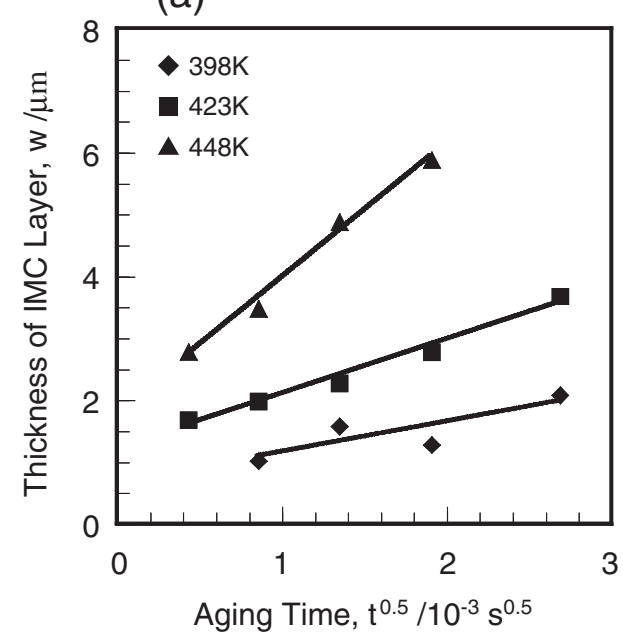

(b)

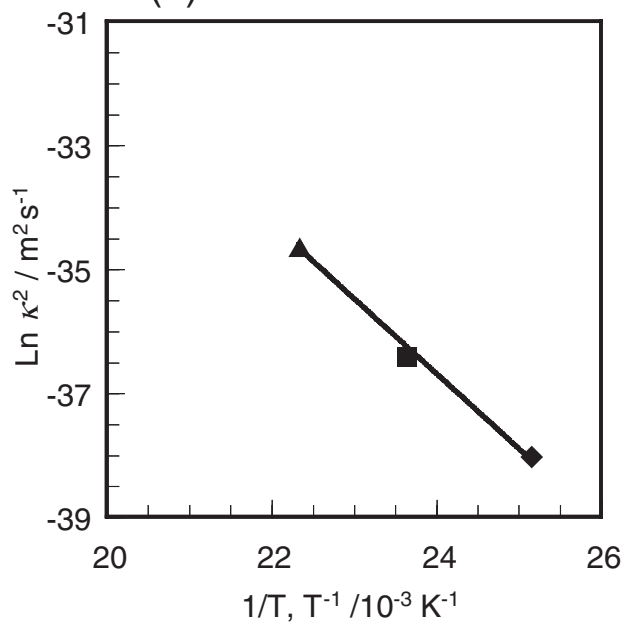

Fig. 16 (a) Average thickness of the IMC layer of $\mathrm{Sn}-37 \mathrm{~Pb}$ solder/electrolytic Ni joints with aging time and temperature and (b) Arrhenius plot for the growth of the IMC layer.

$$
k=A \exp (-Q / R T)
$$

where $A$ is a prefactor, $T$ is the absolute temperature, $R$ is the gas constant and $Q$ is the effective activation energy of the reaction. An Arrhenius plot, as shown in Figs. 14(b)-16(b), is obtained for the three solders $(\mathrm{Sn}-3 \mathrm{Ag}-0.5 \mathrm{Cu}, \mathrm{Sn}-3.5 \mathrm{Ag}$ and $\mathrm{Sn}-37 \mathrm{~Pb}$ ) using the electrolytic Ni UMB systems. The activation energy for the IMC growth in the solid state reaction is estimated to be $95 \mathrm{~kJ} / \mathrm{mol}$ for the $\mathrm{Sn}-3 \mathrm{Ag}-0.5 \mathrm{Cu}$ solder, $106 \mathrm{~kJ} / \mathrm{mol}$ for the $\mathrm{Sn}-3.5 \mathrm{Ag}$ solder and $101 \mathrm{~kJ} / \mathrm{mol}$ for the $\mathrm{Sn}-37 \mathrm{~Pb}$ solder with electrolytic Ni UBM, respectively. The similarity in the $Q$ values in all of the systems indicates the same diffusion-controlled process in IMC growth in this system.

As shown in Fig. 15(b), the growth rate of the $\mathrm{Sn}-3.5 \mathrm{Ag}$ solder/Ni UBM at 463 and $473 \mathrm{~K}$ was slightly higher than expected from the Arrhenius plot between 398 and $448 \mathrm{~K}$. This tendency was also seen in $\mathrm{Sn}-3 \mathrm{Ag}-0.5 \mathrm{Cu}$ solder/Ni UBM [Fig. 14(b)]. The activation energy in Sn-3.5Ag solder in the higher-temperature region is estimated to be $178 \mathrm{~kJ} /$ $\mathrm{mol}$, and in the lower-temperature region to be $80 \mathrm{~kJ} / \mathrm{mol}$, shown as the dotted line in Fig. 15(b). Similar results of accelerated growth at higher aging temperature can be found in previous reports, but without any discussion ${ }^{3,10,16)}$ except for Yoon et al. $^{5)}$ Figure 17 shows growth rates in several systems of high $\mathrm{Sn}$ and pure $\mathrm{Ni}$, which were re-plotted from previous works. ${ }^{10,16,17)}$ Because these data show fairly good agreement, this result is essential. Yoon et al. reported similar results in $\mathrm{Sn}-0.7 \mathrm{Cu}$ solder/Cu/Ni/Au UBM at temperatures between 343 and $443 \mathrm{~K}$. In addition, the growth rate of the total IMC layer after aging for $4.32 \times 10^{6} \mathrm{~s}$ at $443 \mathrm{~K}$ becomes very high due to the formation of $(\mathrm{Ni}, \mathrm{Cu})_{3} \mathrm{Sn}_{4}$ added to the original $(\mathrm{Ni}, \mathrm{Cu})_{6} \mathrm{Sn}_{5}$ layer. ${ }^{5)}$ However, as the EPMA line profile of the IMCs as shown in Fig. 13, the $\mathrm{Sn}-\mathrm{Ag}$ solder joint has mono $\mathrm{Ni}_{3} \mathrm{Sn}_{4}$ IMC in this work. Therefore, this result differs essentially from the results of Yoon et al. ${ }^{5)}$ From the results of $\mathrm{Sn}-3 \mathrm{Ag}-0.5 \mathrm{Cu}$ solder, the growth rate of the low-temperature region has been somewhat accelerated by adding $\mathrm{Cu}$. The activation energy change implies that the contribution of grain boundary diffusion diminishes and the
Sn-3.5Ag/Electrolytic Ni (This Work)

Sn-3.5Ag/Sputtered $\mathrm{Ni}$ (He et al)

$\Delta$ Dipped Sn/Ni sheet (Olsen)

- Plated Sn/Ni sheet (Olsen)

Molten Sn-3.5Ag/Electrolytic Ni (Yamashita)

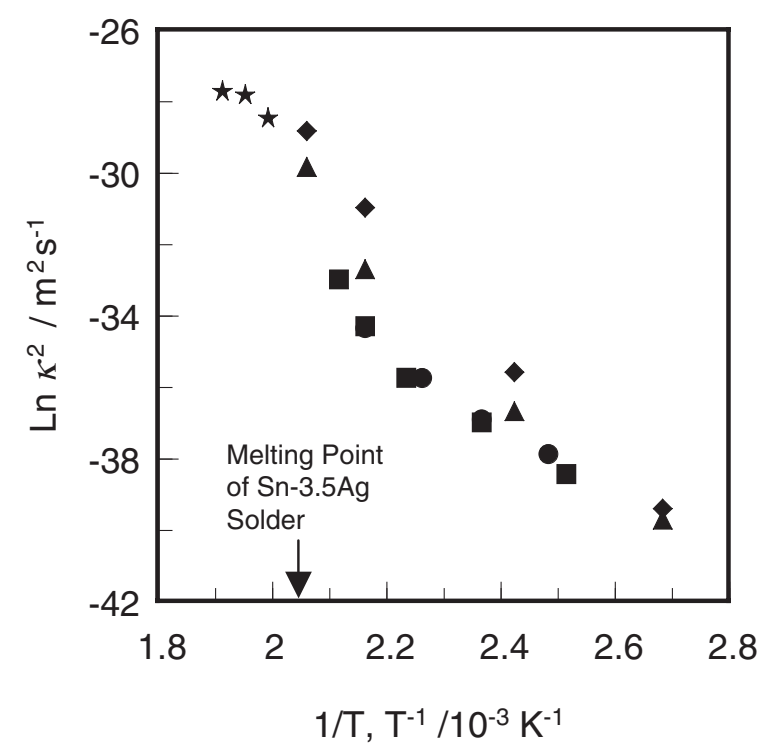

Fig. 17 Arrhenius plot for the growth of the IMC layer including the results of previous research.

volume diffusion predominates as the layer grows thicker and grain coarsening progresses.

\subsection{Void formation at the IMC/solder interface}

When the aging temperature was at $473 \mathrm{~K}$, large voids were observed in the $\mathrm{Sn}-3 \mathrm{Ag}-0.5 \mathrm{Cu}$ solder after $0.72 \times 10^{6} \mathrm{~s}$ and in the $\mathrm{Sn}-3.5 \mathrm{Ag}$ solder after $1.8 \times 10^{6} \mathrm{~s}$. They were also observed in the $\mathrm{Sn}-3 \mathrm{Ag}-0.5 \mathrm{Cu}$ solder at $463 \mathrm{~K}$ after $0.72 \times$ $10^{6} \mathrm{~s}$ and in the $\mathrm{Sn}-3.5 \mathrm{Ag}$ solder after $1.8 \times 10^{6} \mathrm{~s}$. During the solid state interactions, Kirkendall voids are often formed at the interface of the IMC and solder. However, since an $\mathrm{Ni}$ 
layer still remains in the sample, the void formation is not attributed to Ni consumption. Under the conditions in which the voids formed, $\mathrm{Ni}$ atom supply was limited due to diffusion through thick IMC. Therefore, Sn diffusion may predominate over $\mathrm{Ni}$ at the interface of IMC and solder. These voids were the result of unbalanced elemental diffusion. However, the voids were only observed at the center of contour line between the IMC and solder, not in the peripheral area. This shows the influence of other factors.

The outer parts of IMC swelled in Figs. 9, 11. This implies that the formation of IMC caused the volume expansion of the original Ni layer and reduction of the solder body. This led to the generation of shear stress along the outer radical direction at the interface between the IMC and solder. Shear stress may induce the accumulation of vacancies and deformation in the bumps to relieve the stress, and as a result of the formation of voids.

In Figs. 9, 11, some coarse $\mathrm{Ag}_{3} \mathrm{Sn}$ grains were formed in the solder bodies. $\mathrm{Ag}_{3} \mathrm{Sn}$ and the IMC layer have strong hardness and poor ductility. ${ }^{12)}$ Since the surroundings of $\mathrm{Ag}_{3} \mathrm{Sn}$ are especially heterogeneous in their mechanical properties, it is presumed that voids are easily initiated at the area and propagated. The reason for there being no voids with the $\mathrm{Sn}-37 \mathrm{~Pb}$ solder may be stress release by the ductile $\mathrm{Pb}$ phase accumulated at the interface.

\section{Conclusions}

In this work, we fabricated $\mathrm{Sn}-3 \mathrm{Ag}-0.5 \mathrm{Cu}$ solder, $\mathrm{Sn}-$ $3.5 \mathrm{Ag}$ solder and $\mathrm{Sn}-37 \mathrm{~Pb}$ solder bumps with $110-\mu \mathrm{m}$ diameter solder balls on electrolytic Ni UBM, and investigated the growth kinetics of intermetallic compound (IMC) layers and the morphology of bumps during long-term aging.

(1) The IMC layer exhibited parabolic growth, and the activation energy values for the $\mathrm{Sn}-3 \mathrm{Ag}-0.5 \mathrm{Cu}, \mathrm{Sn}-$ $3.5 \mathrm{Ag}$ and $\mathrm{Sn}-37 \mathrm{~Pb}$ solder $/ \mathrm{Ni} \mathrm{UBM}$ were obtained with 95,106 and $101 \mathrm{~kJ} / \mathrm{mol}$, respectively.

(2) The growth rate accelerated at $463 \mathrm{~K}$ or above in the $\mathrm{Sn}-3.5 \mathrm{Ag}$ solder. The activation energy for the higher- temperature region is estimated to be $178 \mathrm{~kJ} / \mathrm{mol}$ and for the lower-temperature region to be $80 \mathrm{~kJ} / \mathrm{mol}$. This tendency was also seen in the $\mathrm{Sn}-3 \mathrm{Ag}-0.5 \mathrm{Cu}$ solder.

(3) $(\mathrm{Ni}, \mathrm{Cu})_{3} \mathrm{Sn}_{4}$ or $\mathrm{Ni}_{3} \mathrm{Sn}_{4}$ IMC was formed mainly at the solder/Ni interface after long-term aging.

(4) Large voids were formed at the interface between the solder and IMC at $463 \mathrm{~K}$ or above. The voids are the result of stress by volume expansion due to IMC growth. Coarse $\mathrm{Ag}_{3} \mathrm{Sn}$ grains were observed adjacent to the voids and contributed to void initiation.

\section{REFERENCES}

1) D. Napp: SAMPE Journal 32 (1996) 59-65.

2) K. H. Lau: Flip Chip Technologies, (McGraw-Hill, New York, 1995) 25-28.

3) J. W. Yoon, S. W. Kim and S. B. Jung: Mater. Trans. 45 (2004) 727733.

4) A. Sharif, M. N. Islam and Y. C. Chan: Mater. Sci. Eng. B 113 (2004) 184-189.

5) J. W. Yoon, S. W. Kim and S. B. Jung: J. Alloys Compd. 391 (2005) 82-89.

6) K. Zeng and K. N. Tu: Mater. Sci. Eng., Elsevier Science, R 38 (2002) 55-105.

7) C. Y. Liu, K. N. Tu, D. R. Frear and P. Elenius: J. Appl. Phys. 87 (2000) 750-754.

8) Y. Kariya, K. Nakamura, Y. Tanaka and M. Otsuka: 6th Symp on MATE, JWS (2000) 217-222.

9) M. He, W. H. Lau, G. Qi and Z. Chen: Thin Solid Films 462-463 (2004) 376-383.

10) M. He, A. Kumar, P. T. Yeo, G. J. Qi and Z. Chen: Thin Solid Films 462-463 (2004) 387-394.

11) Y. D. Jeon, A. Ostmann, H. Reichl and K. W. Paik: Proc. 53th ECTC, IEEE (2003) 1203-1208.

12) D. Li, C. Liu and P. P. Conway: Mater. Sci. Eng. A 391 (2005) 95-103.

13) E. Hashino, K. Shimokawa, Y. Yamamoto and K. Tatsumi: Proc. 51th ECTC, IEEE (2001) 957-964.

14) S. Terashima, Y. Kariya and M. Tanaka: Mater. Trans. 45 (2004) 637680.

15) W. T. Chen, C. E. Ho and C. R. Kao: J. Mater. Res. 17 (2002) 263-266.

16) D. Olsen, R. Wright and H. Berg: 13th Ann. Proc. Reliability. Phys. SymP., (1975) 80-86.

17) S. Yamashita, M. Harada, K. Yamamoto and R. Kimoto: 37th MATE, JWS (2004) 51-59. 